\title{
NOTE
}

\section{Use of random amplified polymorphic DNAs (RAPDs) in separating two sibling species of Littorina}

\author{
S. Crossland, D. Coates, J. Grahame, P. J. Mill \\ Department of Pure and Applied Biology, University of Leeds, Leeds LS2 9JT, United Kingdom
}

\begin{abstract}
Unlike the results of other comparative approaches, random amplified polymorphic DNA patterns from sympatric populations of Littorina saxatilis and $L$. arcana show clear differences. Analysis of the data using the method of Nei \& Li (1979; Proc. natn. Acad. Sci. U.S.A. 76:5269-5273) separates individuals of the species into 2 discrete groups, supporting the view that their species status is justified.
\end{abstract}

The Littorina saxatilis species complex is widely considered to consist of 4 closely related species L. saxatilis (Olivi), L. arcana Hannaford Ellis, L. nigrolineata Gray and L. neglecta Bean. L. arcana was described as a separate species by Hannaford Ellis (1978), and while other workers were sometimes sceptical of the specific status of this form (Caugant \& Bergerard 1980. Smith 1982) the consensus has arisen that $L$. arcana is a separate species (e.g. Ward 1990). The species are usually impossible to distinguish in the field.

Extensive enzyme polymorphism studies have been carried out on the 2 species (e.g. Berger 1973, 1977. Janson \& Ward 1984, Ward \& Janson 1985, Ward et al. 1986, Mill \& Grahame 1988) with some limited success at separation. However, as breeding experiments are very difficult with these organisms (Warwick 1983, Warwick et al. 1990), it may not be easy to interpret these studies genetically. Where there are sufficient data to calculate genetic distance information, the finding is that variation within the 2 taxa is as great as, or greater than, variation between them (e.g. Ward \& Janson 1985, Knight et al. 1987). This pattern is reflected in morphometric studies where it has been shown that Littorina saxatilis may more closely resemble L. arcana in the absence of the latter species, giving rise to the possibility of character displacement (Grahame \& Mill 1986).
The method of random amplified polymorphic DNAs (RAPDs) was developed independently by 2 groups in 1990 (Welsh \& McLelland 1990, Williams et al. 1990). It was originally seen as a method for biotyping bacteria. However, it was quickly recognised as useful for population. studies and has been successfully employed as such (Caetano-Anolles et al. 1991, Chapco et al. 1992). RAPDs is an adaptation of the Polymerase Chain Reaction (PCR) (see Innis et al. 1990). It relies on the rationale that at low stringency, a given synthetic oligonucleotide primer is likely to find a number of sequences in the template DNA to which it can anneal. When these sites are close to each other, and lie in opposite orientations, the DNA sequence between the sites will be amplified to produce a DNA fragment characteristic of that genome. Multiple bands of different sizes produced from the same genomic DNA constitute a 'fingerprint' of that genome. Patterns from different individuals and species will vary as a function of how similar the genomic DNA sequences are between samples. Consequently, arbitrary primers will reveal polymorphisms which act as genetic markers, similar to restriction fragment length polymorphisms (RFLPs). The lengths of primers used by different workers varies; Welsh \& McLelland (1990) used 2 primers separately, one a $20 \mathrm{mer}$, the other a $34 \mathrm{mer}$. Williams et al. (1990) used 10mers and Caetano-Anolles et al. (1991) produced very complex data by using primers of only 5 bases in length.

This report describes the use of several primers to differentiate between sympatric Littorina saxatilis and L. arcana populations.

Materials and methods. Specimens were collected from Millendreath, Cornwall, UK, from a $50 \mathrm{~m}$ stretch of continuous bedrock. Individuals were removed 
from their shells and identified by their reproductive tracts. Females can be easily assigned to species, with Littorina saxatilis brooding its young in a pouch formed from the mantle cavity, and $L$. arcana having a characteristic jelly gland (Hannaford Ellis 1979). Males cannot be reliably assigned to species, and therefore were excluded from this study. Total genomic DNA was extracted from individuals by a simplified phenol extraction method (Ashburner 1989). Any obviously parasitised specimens were discarded. As a further precaution against contamination by parasites, only the head-foot was used for extraction, since parasites mainly inhabit the digestive tract. After thorough washing with several $0.5 \mathrm{ml}$ aliquots of $10 \mathrm{mM}$ Tris- $\mathrm{Cl}(\mathrm{pH} 7.5)$, the tissue was homogenised in $100 \mu \mathrm{l}$ of homogenisation buffer [10 mM Tris-Cl (pH 7.5), $60 \mathrm{mM} \mathrm{NaCl}, 10 \mathrm{mM}$ EDTA made up to $5 \%$ sucrosel. Spermine and spermidine were added to the homogenisation buffer immediately before use to a final concentration of $0.15 \mathrm{mM}$. The homogenate was then lysed with 1 volume of a lysis buffer containing $300 \mathrm{mM}$ Tris-Cl (pH 9), $100 \mathrm{mM}$ EDTA, 5\% sucrose and $0.625 \%$ SDS. After incubation at $37^{\circ} \mathrm{C}$ for $30 \mathrm{~min}, 30 \mu \mathrm{l}$ of $8 \mathrm{M}$ potassium acetate was added.
The lysed homogenate was incubated on ice for 30 min, followed by extraction with phenol:chloroform: isoamyl alcohol $(25: 24: 1)$. The DNA in the resulting aqueous phase was precipitated with absolute ethanol, washed in $70 \%$ ethanol, and resuspended in $1 / 10 \times$ TE buffer ( $\mathrm{pH} 8.0)(1 / 10 \times \mathrm{TE}$ is $10 \mathrm{mM}$ Tris, 1 mM EDTA). Amounts of resuspended DNA were quantified by gel electrophoresis and the concentra-

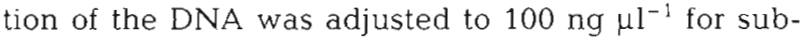
sequent PCR reactions. Four primers were used; these were chosen from existing laboratory stocks and varied in length from 10 to 24 bases. The PCR reactions were carried out in $50 \mu \mathrm{l}$ volumes $[10 \mathrm{mM}$ Tris-Cl (pH 9.0), $50 \mathrm{mM} \mathrm{KCl}, 0.01 \%$ (w/v) gelatin, $1.5 \mathrm{mM} \mathrm{MgCl}_{2}, 0.1 \%$ Triton X-100] with 0.5 units of Taq Polymerase and $200 \mathrm{pmol}$ of primer per tube. The tubes were raised to $95^{\circ} \mathrm{C}$ for $5 \mathrm{~min}$, then cycled 45 times through temperatures of $95^{\circ} \mathrm{C}$ for $1 \mathrm{~min}$ (denaturation step), $35^{\circ} \mathrm{C}$ for $1 \mathrm{~min}$ (annealing step) and $72^{\circ} \mathrm{C}$ for $2 \mathrm{~min}$ (extension step). A final step of $72^{\circ} \mathrm{C}$ for $5 \mathrm{~min}$ was added to the end of the program to allow complete extension of all amplified fragments. Since DNA concentrations were standardised before a vigorously controlled amplification procedure,
A

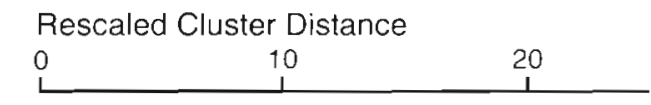

S

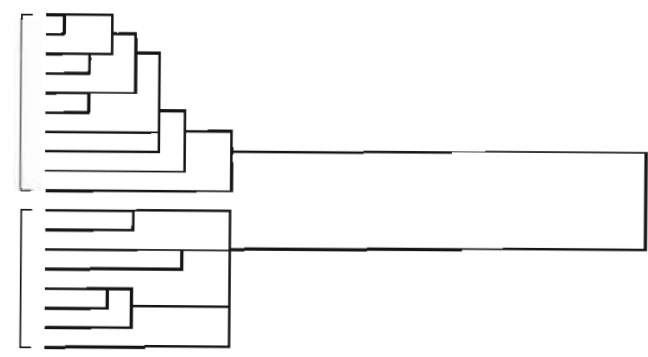

C
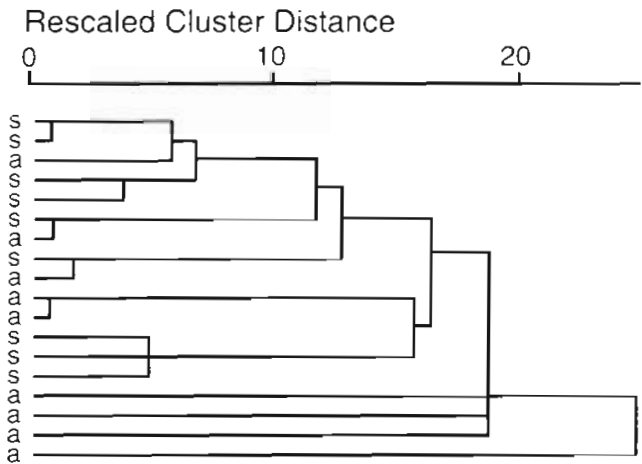

\section{B Rescaled Cluster Distance}
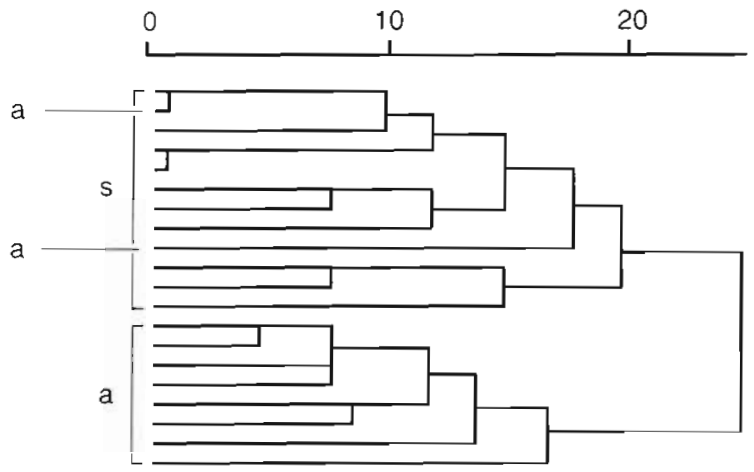

D
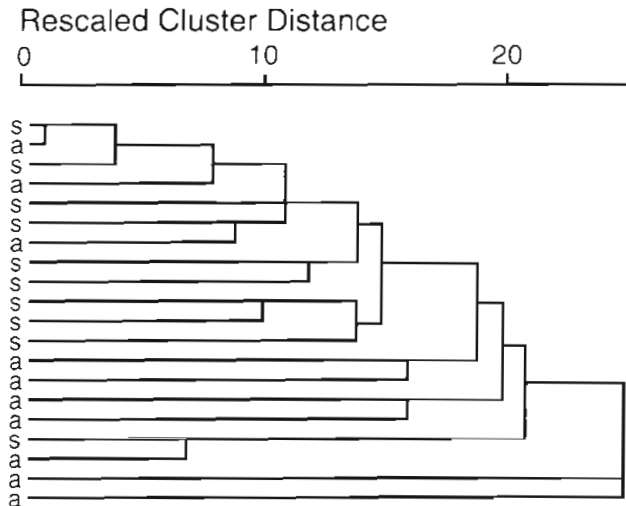

Fig. 1. Dendrograms produced using UPGMA analysis of percentage similarities between individuals, as calculated using the Nei \& Li (1979) F-percent equation. s: Littorina saxatilis, a: L. arcana. (A) Data from Primer $1330(n=18)_{i}(B)$ data from Primer 886 $(n=20) ;(C)$ data from Primer $889(n=20)$; (D) data from Primer $888(n=18)$ 
every effort was made to ensure that final yields were comparable to each other.

Aliquots of each amplified sample $(10 \mu \mathrm{l})$ were run on a $3 \%$ agarose TAE $(40 \mathrm{mM}$ Tris Acetate, $1 \mathrm{mM}$ EDTA) gel [2:1 NuSieve GTG : SeaKem GTG (Flowgen Instruments Ltd)] with a non-blue loading buffer (15\% Ficoll in sterile double-distilled water). The gels were stained with $0.5 \mu \mathrm{g} \mathrm{ml} \mathrm{ml}^{-1}$ ethidium bromide (added to the TAE running buffer) and photographed.

The bands were measured by scanning the photographs with a Chromoscan 3 gel scanner. The scanner produces a trace of peaks which correspond to the bands visible on the photograph. The traces were photocopied onto acetate; shared bands were easily identified by superimposing traces.

Twenty individuals (10 each of Littorina saxatilis and $L$. arcana) were analysed with each of the 4 primers.

Results. For each primer, the number of bands each individual had in common with every other individual was calculated and recorded in a triangular matrix. Then Nei and Li's F-percent analysis (Nei \& Li 1979) was calculated for each pairwise entry in the matrix, giving each pair a percentage similarity index. These data were clustered using UPGMA cluster analysis (using the SPSS statistical package) (Sokal \& Sneath 1963) and the resulting dendrograms drawn for each primer are shown in Fig. 1. The 4 primers all gave different patterns, with varying numbers of bands being produced (Fig. 2; Table 1). The mean ( $\pm \mathrm{SE}$ ) percentage similarity of each group was calculated (Table 1). At various times, DNA has been retested, both by amplifying a fresh aliquot of frozen DNA and by reamplification of bands using band stab PCR (Bjourson \& Cooper 1992). Results from the 5 individuals retested were comparable to the original data set, with the exception of the rare instances when bands of $>1 \mathrm{~kb}$ were produced. These rare bands were sometimes absent from

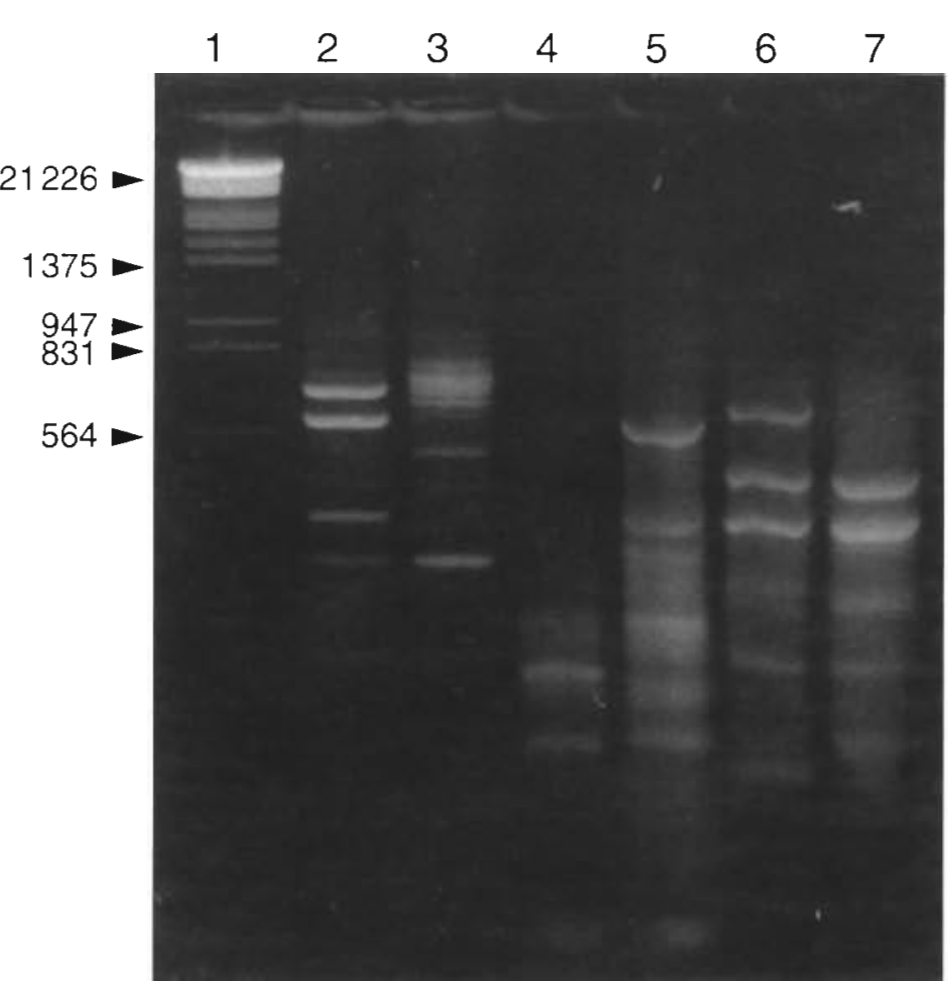

Fig. 2. Bands produced in different individuals using the different primers. Lane 1. $\lambda$ DNA digested with HindIIl and EcoR1 size marker. Lanes 2 \& 3: Littorina saxatilis DNA amplified with Primer 1330. Lane 4: L. saxatilis DNA amplified with Primer 886. Lane 5: L. arcana DNA amplified with Primer 886. Lanes 6 \& 7: L. saxatilis DNA amplified with Primer 889

retested individuals. Because of this, only bands under $1 \mathrm{~kb}$ were included in the analysis.

RAPDs is very sensitive to changing conditions, and several precautions were taken to ensure reproducibility. Minute differences between PCR blocks have been shown to affect banding patterns produced by aphid cDNA (unpubl. data). Consequently, a PCR machine was set aside exclusively for this work. Buffer concentrations were kept uniform by using commercially produced buffer, and by producing large volumes of dNTPs and primer stocks, which covered the duration of the experiment. Precautions taken to prevent

Table 1. Littorina spp. Average number of bands present in each individual ( \pm SE). Mean \% similarities ( \pm SE) within and between species for each primer tested

\begin{tabular}{|rrcrc|}
\hline Primer & $\begin{array}{c}\text { Average no. } \\
\text { of bands }\end{array}$ & $\begin{array}{c}\text { Mean \% similarity } \\
\text { within L. saxatilis }\end{array}$ & $\begin{array}{c}\text { Mean \% similarity } \\
\text { between species }\end{array}$ & $\begin{array}{c}\text { Mean \% similarity } \\
\text { within L. arcana }\end{array}$ \\
\hline 1330 & $5.94 \pm 1.98$ & $40.00 \pm 2.96$ & $8.7 \pm 1.26$ & $55.74 \pm 3.59$ \\
886 & $6.85 \pm 0.96$ & $71.91 \pm 1.85$ & $44.56 \pm 1.33$ & $58.99 \pm 1.81$ \\
889 & $10.15 \pm 1.73$ & $45.00 \pm 1.91$ & $53.73 \pm 1.15$ & $71.66 \pm 2.54$ \\
888 & $2.93 \pm 0.96$ & $65.01 \pm 3.15$ & $66.10 \pm 1.59$ & $77.45 \pm 3.52$ \\
\hline
\end{tabular}


foreign DNA from contaminating the buffers included the use of a UV light box, which disrupts DNA by producing thymine dimers. All solutions, which were aliquoted as described above, were UV treated for $10 \mathrm{~min}$, as were reaction tubes. Careful pipetting ensured the prevention of aerosols - use of Saf-T-Tips (Appligene) specially designed to prevent aerosols was not found to alter results.

Discussion. Enzyme polymorphisms revealed by starch gel electrophoresis have been a popular tool for workers trying to separate species of Littorina (Berger 1973, 1977, Janson \& Ward 1984, Ward \& Janson 1985. Ward et al. 1986, Knight et al. 1987, Knight \& Ward 1991). However, no diagnostic locus has been discovered, despite the large range of enzyme systems studied. Most workers find that the variation exhibited within $L$. saxatilis is at least as great as the variation exhibited between L. saxatilis and L. arcana (Knight \& Ward 1991). It is clear that while allozyme studies can reveal differences between populations, they provide little or no resolution of the taxa. Knight et al. (1987) stated that the clustering of their populations was not robust, due to the large standard errors in their calculations, and they found no evidence of geographical structuring in the dendrograms. The same was indicated in esterase analysis by iso-electric focussing (Mill \& Grahame 1988, 1992). Even though some geographical clustering was evident in these data, the analysis was still not powerful enough to separate $L$. arcana and $L$. saxatilis into 2 discrete taxa. RA.PDs has achieved this, although it is obvious that certain primers indicate greater between-taxon separation than others (Fig. 1). Given the varying nature of the genome, this is not surprising.

It is important for analysis that primers which produce an appropriate number of bands are used. Too many bands mean that difficulties occur in deciding whether or not bands are identical, and too few bands give inaccurate estimates of variability. For example, Primer 1330 separates the taxa into 2 discrete groups. The average number of bands per individual produced by Primer 1330 was $5.94 \pm 1.98$. However Primer 888 produced an average of $2.93 \pm 0.96$ bands per individual, and the subsequent dendrogram reflects the lack of data. From this, with careful primer screening, it is possible to demonstrate genetic variability within even the closest related taxa.

Caugant \& Bergerard (1980) and Smith (1982) have questioned the status of Littorina saxatilis and $L$. arcana as separate species. From this study, we believe that the evidence strongly suggests that there is genetic differentiation between the 2 species, even though it may be minimal, and that their species status is valid. Two of the primers used here indicate greater separation than does any biochemical technique hith- erto applied. We are now using RAPDs to analyse the status of other taxa within the rough periwinkle group and to extend our studies to other shores.

Acknowledgements. The authors thank SERC for funding this research. S.C. would like to thank Adam Corner for his helpful advice and for donating primer samples, Dave Briggs for donating primer samples, Nancy Clarkson for proof reading and corrections, and Mrs Gillian Wroughton for helping with the collection of the specimens.

\section{LITERATURE CITED}

Ashburner, M. (1989). Drosophila: a laboratory manual. Cold Spring Harbor Laboratory Press

Berger, E. M. (1973). Gene-enzyme variation in three sympatric species of Littorina. Biol. Bull. 145: 83-90

Berger, E. M. (1977). Gene-enzyme variation in three sympatric species of Littorina. II. The Roscoff population with a note on the origin of $\mathrm{N}$. American L. littorea. Biol. Bull. 153: $255-264$

Bjourson, A. J., Cooper, J. E. (1992). Band stab PCR - a simple technique for the purification of individual PCR products. Nucl. Acids Res. 20 (17): 4675

Caetano-Anolles, G., Bassam, G. J., Gresshof, P. M. (1991). High resolution DNA amplification fingerprinting using very short arbitrary oligonucleotide primers. Biotechnol. 9: $553-556$

Caugant, D., Bergerard, J (1980). The sexual cycle and reproductive modality in Littorina saxatilis Olivi (Mollusca: Gastropoda). Veliger 23: 107-111

Chapco, W., Ashton, N. W., Martel, R. K. B., Antonishyn, N. (1992). A feasibility study of the use of random amplified polymorphic DNA in the population genetics and systematics of grasshoppers. Genome 35: 569-574

Grahame, J., Mill, P. J. (1986). Relative size of the foot in two species of Littorina on a rocky shore in Wales. J. Zool., Lond. 208: 229-236

Hannaford Ellis, C. J. (1978). Littorina arcana sp. nov. : a new species of winkle (Gastropoda: Prosobranchla: Littorinidae). J. Conchol. 29: 304

Hannaford Ellis, C. J. (1979). Morphology of the oviparous rough winkle $L$ arcana Hannaford Ellis, with notes on the taxonomy of the $L$. saxatilis species complex (Prosobranchia: Littorinidae). J. Conchol. 30: 43-56

Innis, V. A., Gelfland, D. H., Sninsky, J. J., White, T. J. (1990). PCR protocols: a guide to practıcal applıcations. Academic Press, Inc., New York

Janson, K., Wàrd, R. D. (1984). Microgeographic variation in allozyme and shell characters in Littonna saxatilis (OIiv)) (Prosobranchia, Littorinldae). Biol. J. Linn. Soc. 22: $289-307$

Knight, A. J, Hughes, R. N., Ward, R. D. (1987) A striking example of the founder effect in the mollusc Littorina saxatilis. Biol. J. Linn. Soc. 32: 417-426

Knight, A. J., Ward, R. D. (1991). The genetic relationships of three taxa in the Littorina saxatilis species complex (Prosobranchia: Littormidae). J. mollusc. Stud. 57: 81-91

Mill, P. J., Grahame, J W (1988). Esterase variability in the gastropods L. saxatilis (Olivi) and L. arcana Hannaford Ellis. J. mollusc. Stud. 54:347-353

Mill, P. J., Grahame, J. W. (1992). Clinal changes in Littorina saxatilis (Olıvi) and L. arcana Hannaford Ellis in Southern 
Britain. In: Grahame, J., Mill, P. J., Reid, D. G. (eds.) Proceedings of the third International Symposium on Littorinid Biology. The Malacological Society of London. London, p. 1-7

Nei, M. Li, W.-H. (1979). Mathematical model for studying genetic variation in terms of restriction endonucleases. Proc. natn. Acad. Sci. U.S.A. 76: 5269-5273

Smith, S. M. (1982). A review of the genus Littorina in British and Atlantic waters (Gastropoda: Prosobranchia). Malacologia 22: 535-539

Sokal, R. R., Sneath, P. H. A. (1963). Principles of numerical taxonomy. Freeman, San Francisco

Ward, R. D. (1990). Biochemical genetic variation in the genus Littorina (Prosobranchia: Mollusca). Hydrobiologia 193: $53-69$

Ward, R. D., Janson, K. (1985). A genetic analysis of sympatric sub-populations of the sibling species $L$. saxatilis (Olivi)

This note was presented by R. N. Hughes, Bangor, UK and L. arcana Hannaford Ellis. J. mollusc. Stud. 51: 86-94 Ward, R. D. Warwick, T., Knight, A. J. (1986). Genetic analysis of ten polymorphic en yme loci in $L$. saxatilis (Prosobranchia: Mollusca). Heredity 57: 233-241

Warwick, I (1983). A method of maintaining and breeding members of the Littorina saxatilis (Olivi) species complex. J. mollusc. Stud. 48: 368-370

Warwick, T., Knight, A. J, Ward, R. D. (1990). Hybridisation in the Littorina saxatilss species complex (Prosobranchia: Mollusca). Hydrobiologia 193: 109-116

Welsh, J., McClelland, M. (1990). Fingerprinting genomes using PCR with arbitrary primers. Nucl. Acids Res. 18: $7213-7218$

Williams, J. G. K., Kubelik, A. R., Livak, K. J, Rafalskı, J. A., Tingey, S. V. (1990). DNA polymorphisms amplified by arbitrary primers are useful as genetic markers. Nucl. Acids Res. 18: 6531-6535

Manuscript first received: January 18, 1993 Revised version accepted: March 26, 1993 